\title{
The effect of intravenous infusions of sterculic acid on milk fat synthesis
}

\author{
By R. BICKERSTAFFE AND A. R. JOHNSON* \\ Unilever Research Laboratory, Colworth House, Sharnbrook, Bedford
}

(Received I4 September 1971 - Accepted 23 November 1971)

\begin{abstract}
I. The effects of intraduodenal infusions of sterculic acid, a naturally occurring inhibitor of desaturase activity, on the yield and composition of milk were examined in a lactating goat. 2. Sterculic acid administration incrcased the percentage of stearic acid in milk fat, reflecting inhibition of mammary desaturase activity. Milk yield was not affected, but milk fat output decreased. Possible explanations are discussed.

3. No evidence was obtained for an alternative pathway of oleic acid synthesis from acetate.
\end{abstract}

In ruminants, short-chain fatty acids up to a chain length of $\mathrm{C}_{14}$ and part of the $\mathrm{C}_{16}$ in milk fat originate by de novo synthesis from acetate and $\beta$-hydroxybutyrate absorbed from circulating blood (see Linzell, I 968). The longer-chain fatty acids with I 8 carbon atoms and part of the fatty acids with $\mathrm{x} 6$ carbon atoms in milk fat are derived direct from plasma lipids (Annison, Linzell, Fazakerley \& Nichols, I 967; Bishop, Davies, Glascock \& Welch, I 969$)$. Substantial quantities of absorbed stearate are converted into oleate in the mammary tissue of lactating goats (Annison et al. x967; Bickerstaffe $\&$ Annison, 1970) and cows (Lauryssens, Verbeke, Peeters, Garton, Lough \& Duncan, I960), by a desaturase enzyme located in the microsomal particles (Bickerstaffe \& Annison, I968, 1970). The desaturase enzyme in plant tissues (James, Harris \& Bezard, r 968 ) and animal tissues (Raju \& Reiser, 1967; Allen, Johnson, Fogerty, Pearson \& Shenstonc, 1967 ; Donaldson, $1967 a$ ) is inhibited by the cyclopropene fatty acid, sterculic acid. On the basis of experiments with adult rats in which the desaturase system was inhibited by sterculic acid, oleic acid has been proposed to be synthesized from acetate by $\beta$ - $\gamma$-desaturation of synthesized lauric acid followed by elongation rather than desaturation of stearic acid (Raju \& Reiser, 1969). According to some workers this pathway is induciblc in chicks (Donaldson, $1967 b$ ). Doubts have been expressed regarding the existence of such a pathway (Pearson, Fogerty, Johnson \& Shenstone, r972; Coleman \& Friedman, 1971).

In the present work we have examined the effect of sterculic acid on the desaturase enzyme system in mammary tissue and on milk fat synthesis by measuring arteriovenous differences of fatty acid concentration across the mammary gland and the fatty acids secreted in milk in a surgically prepared lactating goat. Milk yield was not affected but milk fat synthesis was reduced on infusing intravenously sterculic acid. Increased concentrations of stearic acid in milk fat reflected the inhibition of the desaturase enzyme by sterculic acid, but an alternate pathway to oleic acid, as assayed by the incorporation of $\left[\mathrm{U}-{ }^{14} \mathrm{C}\right]$ acetate into milk fatty acids, was not observed.

* Permanent address: CSIRO Division of Food Research, Ryde, NSW, Australia. 
EXPERIMENTAL

Animal. A lactating goat was prepared for mammary arteriovenous sampling and measurement of udder blood flow as described by Linzell (1960). The goat was given I $100-1200 \mathrm{~g} / \mathrm{d}$ of a concentrate $(\mathrm{kg} / \mathrm{I} 00 \mathrm{~kg}$ : maize 25 , barley 22 , decorticated cotton cake ${ }_{15}$, malt culms 4 , tallow 2 , distillers' grain 10 , meat meal 3 , rice bran 3 , milo Io and molasses 5) in twenty-four hourly feeds, and $500 \mathrm{~g}$ hay/d at 09.30 and 16.00 hours in two feeds. The goat was housed in a metabolism crate and water was freely available.

Infusion of sterculic acid. Methyl sterculate was prepared from Sterculia foetida L. seeds by the procedure of Kircher (1964) and its purity established as $98 \%$ by thinlayer chromatography on silver nitrate impregnated silica gel followed by hydrogenation and identification of the products by gas-liquid chromatography (Johnson, Murray, Fogerty, Kennett, Pearson \& Shenstone, 1967$)$. A band at 1000-1010 $\mathrm{cm}^{-1}$ in the infrared spectrum of the methyl sterculate, as a liquid film, confirmed the purity and existence of the cyclopropene structure. Portions $(500 \mathrm{mg}$ ) of the ester were saponified with a $10 \%$ excess of $\mathrm{KOH}$ in methanol at $50^{\circ}$; the methanol was removed and $100 \mathrm{ml} 0.9 \%$ sterile saline was added and the volume made up to $200 \mathrm{ml}$ with plasma previously obtained from the goat. The final solutions were continuously infused at $0.13 \mathrm{ml} / \mathrm{min}$ for up to $\mathrm{r} 7 \mathrm{~d}$ into a catheterized jugular vein. Two experiments were carried out; in one the sterculate, after the purity had been checked by its infrared spectra, was infused for $2 \mathrm{~d}$ and in the other, for up to $17 \mathrm{~d}$. Essentially the same results were obtained from both experiments.

Infusion of radioactive fatty acids. A mixture of $\left[\mathrm{I}, \mathrm{I}_{2}-{ }^{3} \mathrm{H}\right]$ stearic acid $(100-200 \mu \mathrm{Ci})$ and [U_-14 $\mathrm{C}$ acetate $(175-380 \mu \mathrm{Ci})$ was saponified as above and $80 \mathrm{ml}$ of the plasmasaline sterculate solution were added. This radioactive infusion solution was infused at $0.13 \mathrm{ml} / \mathrm{min}$ into the catheterized jugular vein for $280-35^{\circ} \mathrm{min}$, and during the last hour of infusion four pairs of arterial and mammary venous blood samples $(3 \circ \mathrm{ml}$ each) were taken simultaneously at I 5-20 min intervals as described by Annison $e t$ al. $\left(\mathrm{I} 66_{7}\right)$. In some experiments $\left[\mathrm{U}_{-}{ }^{14} \mathrm{C}\right]$ acetate only in plasma-saline was infused into the animal.

The animal was milked immediately before the infusion and at intervals of $\mathrm{I} h$ during the infusion, and for $4^{-6} \mathrm{~h}$ after the infusion, using oxytocin (200 m-units) injected intravenously to aid milk ejection. Mammary blood flow was estimated from the milk yield (see Linzell, I97I). Weight of the udder was determined by measurement of the udder volume by displacement of water (Linzell, 1966 ) and assuming that the specific gravity of mammary tissue is $\mathrm{I} \cdot 035$.

Chemical methods. Plasma and milk lipids were analysed and assayed for radioactivity as described by Annison et al. (1967). The level of blood acetate was determined as described by Freeman, Noakes \& Annison (1970) and blood gases, $\beta$-hydroxybutyrate and udder weight as described by Annison, Linzell \& West (1968).

Radioisotopes. $\left[\mathrm{II}_{1} \mathrm{I2}_{2}{ }^{3} \mathrm{H}\right]$ stearic acid $(0.4 \mathrm{mCi} / \mathrm{mg})$ was a generous gift from our colleagues at the Vlaardingen laboratory, Holland. $\left[\mathrm{U}_{-}{ }^{14} \mathrm{C}\right]$ acetate $\left(0 \cdot 5^{6} \mathrm{mCi} / \mathrm{mg}\right)$ was obtained from the Radiochemical Centre, Amersham, Bucks. 


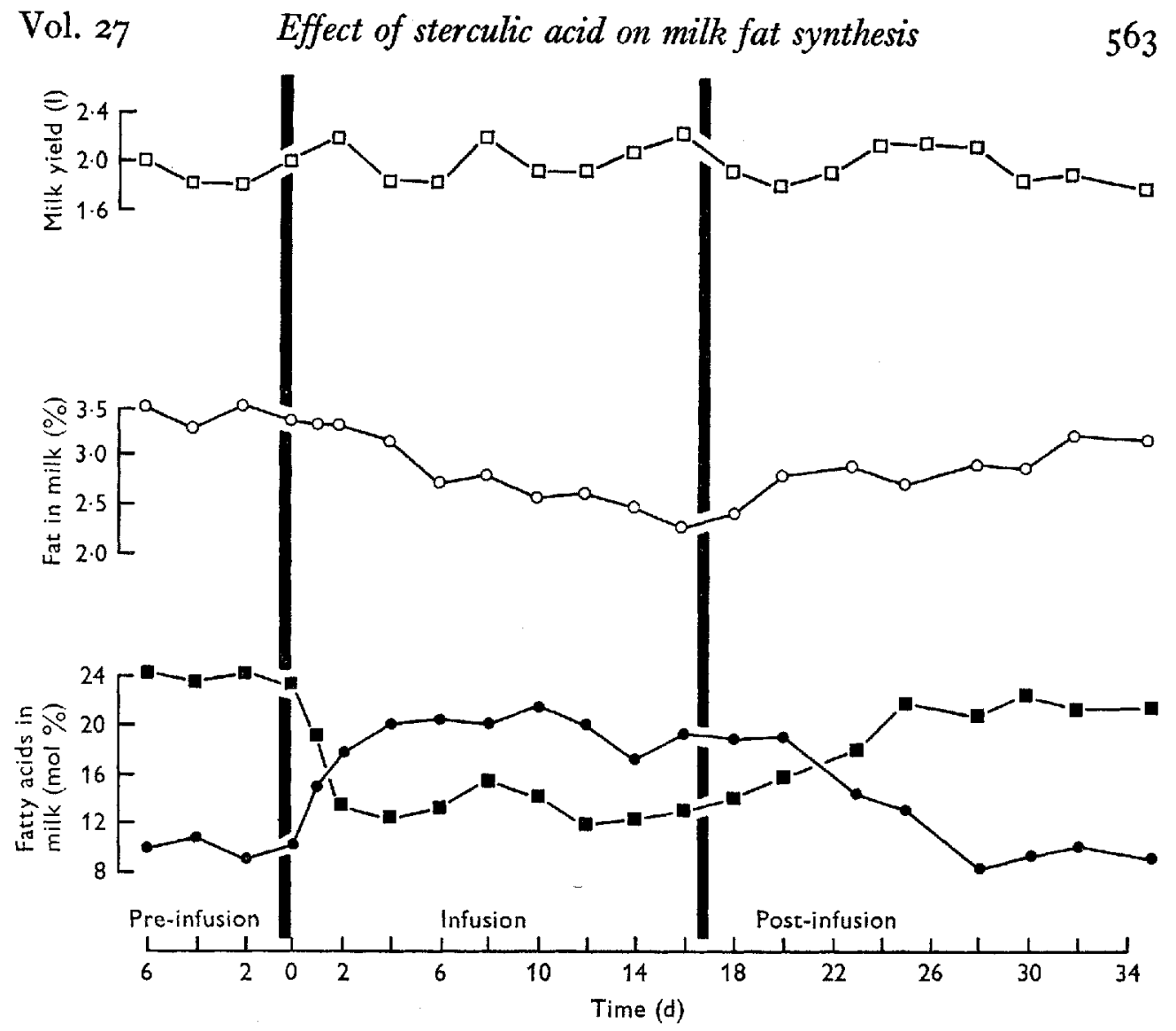

Fig. I. Effect of an intravenous infusion of sterculic acid on milk yield (D) and fat content (O) and the proportion of octadecanoate (18:0) (O) and octadecenoate (18:I) (D) in milk fat in a goat.

\section{RESULTS}

The changes in milk yield, fat content of milk and fatty acid composition of milk fat at given time-intervals before and after intravenous infusions of sterculic acid into a lactating goat are shown in Fig. $x$. The milk yield was largely unaffected by the infusion of sterculic acid; though the fat content of the milk was reduced during the infusion, it subsequently returned to pre-infusion values.

The mean daily intakes of dietary constituents, milk yield and composition of milk in each experimental period are given in Table $\mathbf{r}$. The infusion of sterculic acid had little effect on the intake of dietary constituents, milk yield, lactose or protein content of milk.

Measurement of the arterial levels and arteriovenous differences in $\beta$-hydroxybutyrate, glucose, acetate and lipids in each experimental period (Table 2 ) suggested that a reduction in the mammary uptake of triglyceride, acetate and $\beta$-hydroxybutyrate accompanied the infusion of sterculic acid, with a slow recovery in the post-infusion period. When a continuous intravenous infusion of [U-14C]acetate was given in each experimental period the specific radioactivity of blood acetate and $\mathrm{CO}_{2}$ reached constant values after $240 \mathrm{~min}$. From these values the entry rate and oxidation of 
Table I. Mean daily intake of dietary constituents, milk yields and composition of milk of a goat before, during and after sterculate infusion

\begin{tabular}{|c|c|c|c|}
\hline Dietary intake $(\mathrm{g} / \mathrm{d})$ & $\begin{array}{l}\text { Before } \\
\text { infusion }\end{array}$ & $\begin{array}{l}\text { During } \\
\text { infusion }\end{array}$ & $\begin{array}{c}\text { After } \\
\text { infusion }\end{array}$ \\
\hline Concentrate & 1080 & 1200 & 1200 \\
\hline Hay & 500 & 500 & 500 \\
\hline $\begin{array}{l}\text { Output of } \\
\text { Milk (l/d) } \\
\text { Fat }(\mathrm{g} / \mathrm{d}) \\
\text { Lactose }(\mathrm{g} / \mathrm{d}) \\
\text { Protein }(\mathrm{g} / \mathrm{d})\end{array}$ & $\begin{array}{c}I \cdot 7 \mathrm{I} \\
74 \cdot 0 \\
8 I \cdot 4 \\
49 \cdot 4\end{array}$ & $\begin{array}{l}I \cdot 96 \\
48 \cdot 4 \\
90 \cdot 3 \\
57 \cdot 0\end{array}$ & $\begin{array}{c}x \cdot 97 \\
59 \cdot 1 \\
90 \cdot 0 \\
58.1\end{array}$ \\
\hline $\begin{array}{l}\text { Percentage in milk o } \\
\text { Fat } \\
\text { Solids not fat } \\
\text { Lactose } \\
\text { Protein } \\
\text { Solids }\end{array}$ & $\begin{array}{r}4 \cdot 33 \\
8 \cdot 47 \\
4 \cdot 76 \\
2 \cdot 89 \\
12 \cdot 80\end{array}$ & $\begin{array}{r}2 \cdot 47 \\
8 \cdot 05 \\
4 \cdot 61 \\
2 \cdot 9 x \\
10.52\end{array}$ & $\begin{array}{r}3 \cdot 00 \\
8 \cdot 27 \\
4 \cdot 57 \\
2 \cdot 95 \\
11 \cdot 27\end{array}$ \\
\hline Live weight (kg) & $60 \cdot 0$ & $57 \cdot 0$ & $54 \cdot 0$ \\
\hline
\end{tabular}

acetate in the whole animal and the amount of acetate oxidized in the mammary gland were calculated (Table 3). The infusion of sterculic acid had little effect on the absorption, utilization and oxidation of acetate.

The fatty acid compositions and concentrations of the free fatty acid and triglyceride fractions in arterial and mammary venous plasma, determined in each experimental period are shown in Table 4. Sterculic acid had little effect on the fatty acid composition of the plasma lipids. In contrast, there was a substantial increase in the proportion of stearic acid, accompanied by a reduction in the concentration of oleic acid in the milk fat lipids on infusing sterculic acid (Table 5) implying the inhibition of the desaturase enzyme system in mammary tissue. A comparison of the uptake of individual fatty acids from plasma triglycerides and their secretion into milk fat during each experimental period (Table 6) suggested that stearic acid was in fact converted into oleic acid and that palmitic acid was synthesized endogenously. The results also verify that the desaturation of stearic acid to oleic acid was inhibited by intravenous infusion of sterculic acid.

Determination of the specific activity of plasma free stearic acid after intravenous infusion of $\left[11,12-{ }^{3} \mathrm{H}\right]$ stearic acid in the control and sterculic acid experiments (Table 7) showed that the entry rates of stearic acid were $\mathrm{I} 8 . \mathrm{I}$ and $\mathrm{I} 4.8 \mathrm{mg} / \mathrm{min}$ respectively, which is within the range obtained by previous workers (Annison et al. 1967). In both experiments, the absence of a concentration difference (Table 4 ), but a fall in specific activity (Table 7 ) of free stearic acid across the mammary gland confirmed previous observations that there is substantial uptake of stearic acid by mammary tissue and that stearic acid is released from plasma triglycerides by capillary lipoprotein lipase. The presence of tritium-labelled oleic acid in the arterial and mammary venous plasma indicated that desaturation of intravenously infused stearic acid may occur in extramammary tissues.

Examination of the distribution of radioactivity in milk fat confirmed that stearic 
Vol. 27

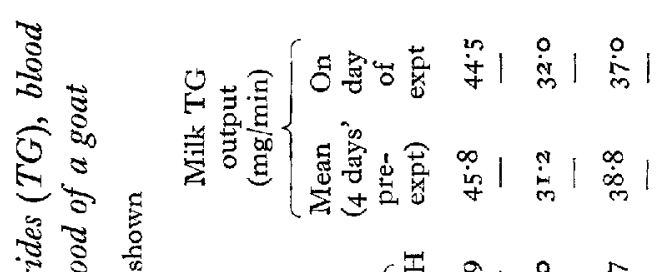

8

.

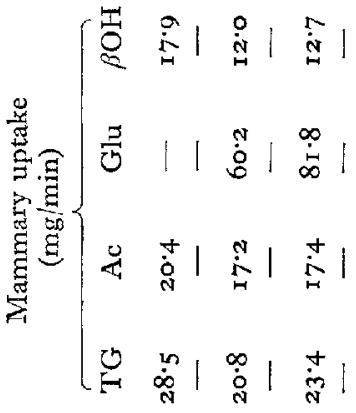

उ्ञ त्र

\&

窟总

国政

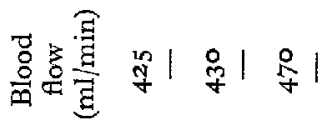

过 可

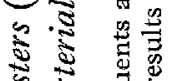

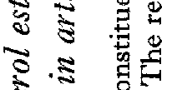

해용

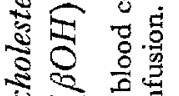

ิิ)

ลิ

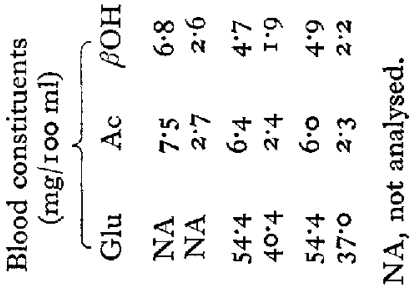

.
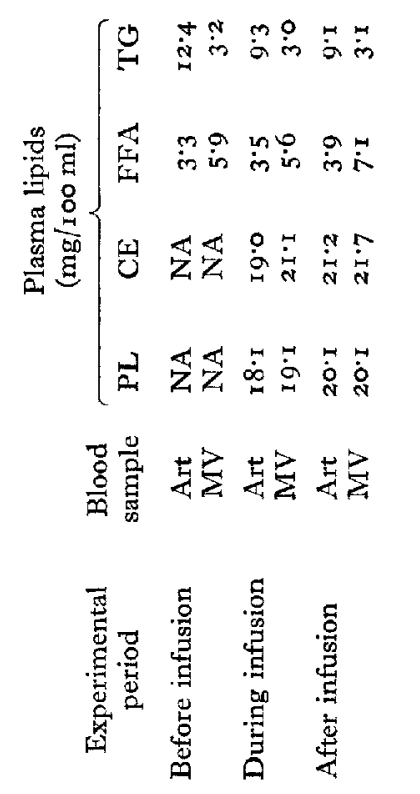
Table 3. Substrate metabolism of $\left[U-{ }^{14} C\right]$ acetate by a lactating goat before, during and after sterculate infusion

\begin{tabular}{|c|c|c|c|}
\hline & $\begin{array}{l}\text { Before } \\
\text { infusion }\end{array}$ & $\begin{array}{l}\text { During } \\
\text { infusion }\end{array}$ & $\begin{array}{l}\text { After } \\
\text { infusion }\end{array}$ \\
\hline $\begin{array}{l}\text { Time acetate infused (min) } \\
\text { Infusion rate }(\mu \mathrm{Ci} / \mathrm{min})\end{array}$ & $\begin{array}{l}310 \\
1 \cdot 216\end{array}$ & $\begin{array}{l}350 \\
0.499\end{array}$ & $\begin{array}{l}275 \\
2 \cdot 170\end{array}$ \\
\hline $\begin{array}{l}\text { Week of lactation } \\
\text { Arterial concentration of }\end{array}$ & 8 & $13-15$ & 17 \\
\hline $\begin{array}{l}\text { Arterial concentration of } \\
\text { substrate }(\mathrm{mg} / \mathrm{1} 00 \mathrm{ml}) \\
\text { Specific activity of arterial acetate }\end{array}$ & $7 \cdot 5$ & $6 \cdot 4$ & $6 \cdot 0$ \\
\hline $\begin{array}{l}\text { ( } \mu \mathrm{Ci} / \mathrm{g} \text { carbon }) \\
\text { Specific activity of arterial } \mathrm{CO}_{2}\end{array}$ & $x 1 \cdot 25^{8}$ & 4.085 & 18.973 \\
\hline $\begin{array}{l}\quad(\mu \mathrm{Ci} / \mathrm{g} \text { carbon) } \\
\text { Entry rate of acetate into circulation }\end{array}$ & $2 \cdot 733$ & $1 \cdot 422$ & 5.523 \\
\hline $\begin{array}{l}\mathrm{mg} / \mathrm{min} \\
\mathrm{mg} / \mathrm{min} \mathrm{kg}\end{array}$ & $\begin{array}{l}270 \\
4.5\end{array}$ & ${ }_{5}^{312}$ & $\begin{array}{l}286 \\
5 \cdot 3\end{array}$ \\
\hline $\begin{array}{l}\text { Total } \mathrm{CO}_{2} \text { from substrate }(\%) \\
\text { Udder weight }(\mathrm{kg}) \\
\text { Mammary uptake of substrate }\end{array}$ & $\begin{array}{l}24 \cdot 3 \\
0.85\end{array}$ & $\begin{array}{c}34.8 \\
0.85\end{array}$ & $\begin{array}{l}29 \cdot 1 \\
0.85\end{array}$ \\
\hline $\begin{array}{l}\text { (mg/min kg tissue) } \\
\text { Mammary } \mathrm{CO}_{2} \text { derived from }\end{array}$ & $24 \cdot 0$ & 20.2 & $20 \cdot 5$ \\
\hline substrate $(\%)$ & $24 \cdot 3$ & $34 \cdot 8$ & $29 \cdot I$ \\
\hline Substrate oxidized $(\%)$ & $63 \cdot 1$ & $77 \cdot 5$ & $57 \cdot 3$ \\
\hline $\begin{array}{l}\text { Mammary substrate uptake as } \\
\% \text { of total entry rate }\end{array}$ & $7 \cdot 6$ & $5 \cdot 5$ & $6 \cdot x$ \\
\hline Respiratory quotient & I'13 & $\mathrm{I} \cdot \mathrm{I} 8$ & $1 \cdot 34$ \\
\hline
\end{tabular}

acid was actively incorporated into milk triglycerides and that stearic acid was desaturated to oleic acid. Determination of the specific radioactivities of stearic and oleic acids showed that $37 \%$ of the stearic acid was desaturated to oleic acid in the pre-infusion period, whereas in the sterculate infusion period only $24 \%$ was desaturated.

The distribution of radioactivity in the milk fatty acids after infusion of $\left[{ }^{14} \mathrm{C}\right]$ acetate (Table 5) showed that acetate was incorporated into fatty acids up to chain length $\mathrm{C}_{\mathrm{I}} 6$ but not into $\mathrm{C} r 8$ fatty acids. The pattern of incorporation was not affected by infusion of sterculic acid.

\section{DISCUSSION}

In the present experiments desaturation of stearic acid in mammary tissue was inhibited by intravenous infusions of sterculic acid, leading to an increased proportion of stearic acid in milk fat. Milk fatty acids are normally $72 \%$ saturated but the infusion of sterculic acid increased the saturation to $84 \%$. Sterculic acid had no significant effect on the fatty acid composition of the plasma free fatty acids or fatty acids of the plasma triglycerides. As the intravenously infused sterculic acid could pass through all organs, the level of desaturase activity in the liver and other tissues of the goat must be very low, with the exception of that of the mammary gland. Thus, as the oleic acid formed by desaturation of stearic acid was retained in the milk fat and not released into the circulation to any extent, and as the mammary gland is a major site for the desaturase enzyme, this enzyme probably controls the ratio of stearic acid to oleic acid in milk fat. 
Vol. 27

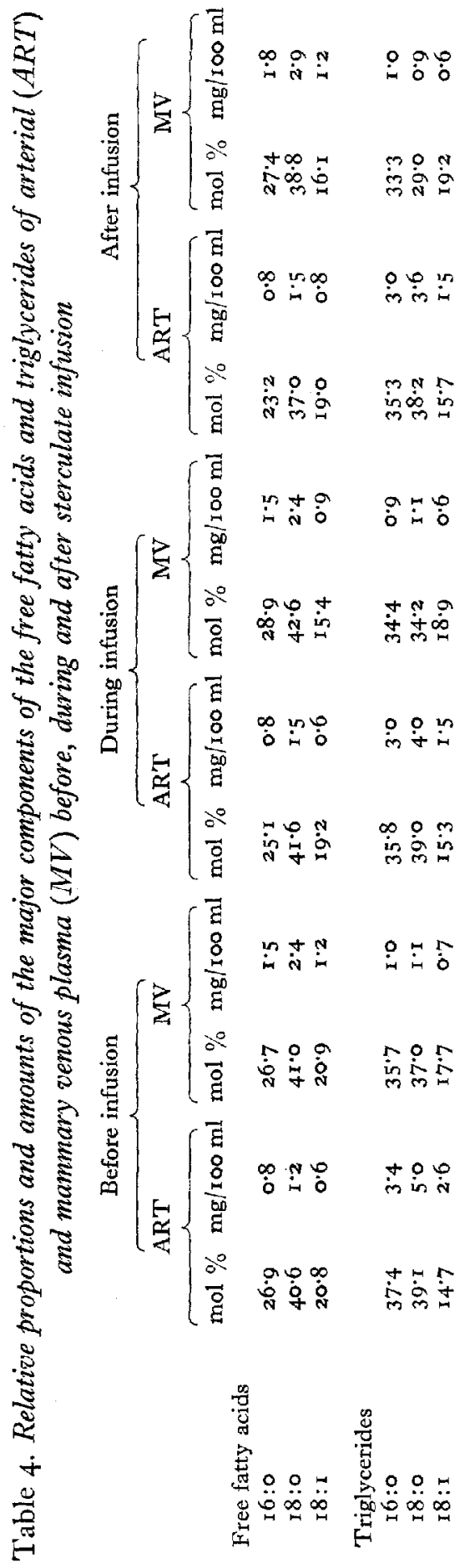


Table 5. Relative proportions and specific radioactivities (SRA) ( $\mu$ Cilg fatty acid) of fatty acids from milk fat of a goat obtained in each experimental period after infusion of $\left[U_{-}{ }^{14} C\right]$ acetate

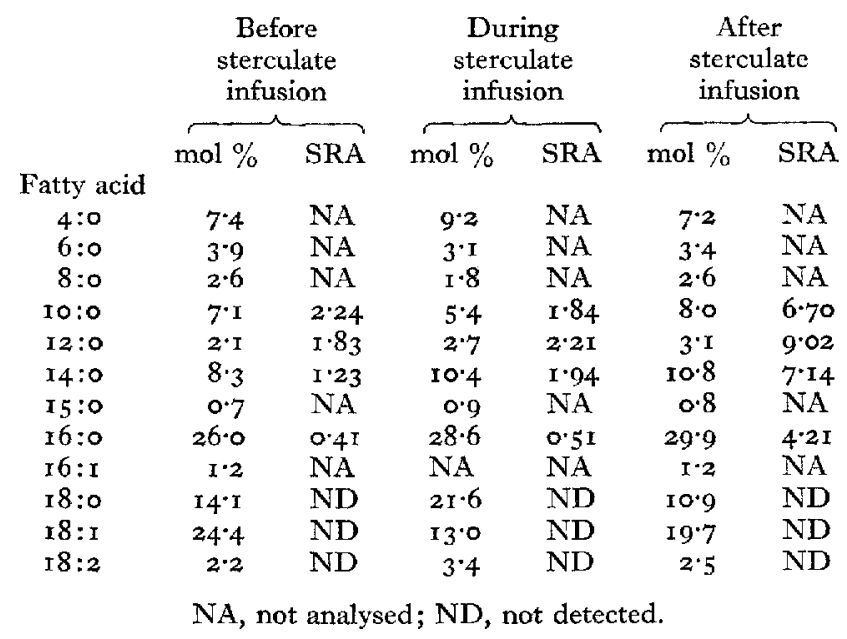

Table 6. Goat mammary gland uptake (from plasma triglyceride) and secretion (as milk triglyceride) of hexadecanoate (I6:0), octadecanoate (18:0) and octadecenoate (18:1) before, during and after sterculate infusion

\begin{tabular}{|c|c|c|c|c|c|c|c|c|}
\hline \multirow[b]{2}{*}{ Experimental period } & \multicolumn{3}{|c|}{$\begin{array}{c}\text { Uptake } \\
(\mathrm{mg} / \mathrm{min})\end{array}$} & \multicolumn{3}{|c|}{$\begin{array}{l}\text { Secretion } \\
(\mathrm{mg} / \mathrm{min})\end{array}$} & \multicolumn{2}{|c|}{$\begin{array}{l}\text { Production } \\
\text { by gland } \\
\text { (mg/min) }\end{array}$} \\
\hline & $16: 0$ & $18: 0$ & I $8: 1$ & I $6: 0$ & I $8: 0$ & I $8: I$ & I 6:0 & $18: 1$ \\
\hline & & $12 \cdot 1$ & & $13 \cdot 0$ & $8 \cdot 4$ & $14 \%$ & $5 \cdot 6$ & $8 \cdot 5$ \\
\hline During infusion & $6 \cdot 9$ & $9 \cdot 6$ & $3 \cdot 0$ & $10 \cdot 0$ & $8 \cdot 4$ & $5 \cdot 0$ & $3 \cdot I$ & $2 \cdot 0$ \\
\hline After infusion & $7 \cdot 8$ & 10.5 & $3 \cdot 5$ & 13.5 & $5 \cdot 5$ & $9^{-8}$ & $5 \cdot 7$ & $6 \cdot 3$ \\
\hline
\end{tabular}

Sterculic acid had no effect on the entry rate or oxidation of acetate, or on milk yield. There was a reduction in the synthesis of milk fat as a consequence of decreased secretion of both long- and short-chain fatty acids and was accompanied, to a certain degree, by a reduction in the uptake of acetate, $\beta$-hydroxybutyrate and triglyceride. There are at least two possible explanations for the reduction in triglyceride synthesis. Maximum activity of the enzyme synthesizing triglycerides could be dependent on the availability of unsaturated fatty acids which normally occupy the 2-position of the glycerol. An excess of saturated fatty acid, i.e. stearic acid, may inhibit the synthesis of triglycerides. Alternatively it is possible that sterculic acid itself could inhibit -SH enzymes, e.g. the glycerol-3-phosphate acyltransferase, responsible for the synthesis of milk fat.

The existence of an alternative pathway for the biosynthesis of oleic acid that does not involve desaturation of stearic acid has been postulated (Raju \& Reiser, 1969), and it has also been suggested that this pathway is induced in chicks when the desaturase enzyme is inhibited by sterculic acid (Donaldson, 19676 ). It is suggested that acetate 
Table 7. Specific radioactivities ( $\mu \mathrm{Ci}{ }^{3} \mathrm{H} / \mathrm{g}$ fatty acid) of the $\mathrm{Cr} 8$ fatty acids in the free fatty acids and triglycerides of arterial (ART) and mammary venous (MV) plasma and the triglycerides of milk fat of a goat in the final stages of perfusing $\left[1 \mathrm{1}, \mathrm{I}_{2}-{ }^{-} \mathrm{H}\right]$ stearic acid

\begin{tabular}{|c|c|c|c|c|}
\hline & \multicolumn{2}{|c|}{$\begin{array}{c}\text { Before } \\
\text { sterculate infusion }\end{array}$} & \multicolumn{2}{|c|}{$\begin{array}{c}\text { During } \\
\text { sterculate infusion }\end{array}$} \\
\hline Infusion time (min) & \multicolumn{2}{|c|}{310} & \multicolumn{2}{|c|}{350} \\
\hline Rate of infusion (nCi/min) & \multicolumn{2}{|c|}{$63 I$} & \multicolumn{2}{|c|}{$\underbrace{266}$} \\
\hline & ART & MV & ART & MV \\
\hline $\begin{array}{l}\text { Plasma free fatty acids } \\
\text { I } 8: 0 \\
\text { I } 8: 1\end{array}$ & $\begin{array}{r}34 \cdot 8 \\
0.3\end{array}$ & $\begin{array}{r}12 \cdot 2 \\
0.3\end{array}$ & $\begin{array}{r}18 \cdot 2 \\
0 \cdot 2\end{array}$ & $\begin{array}{l}6 \cdot 5 \\
0.2\end{array}$ \\
\hline $\begin{array}{l}\text { Plasma triglycerides } \\
\text { I } 8: 0 \\
\text { I } 8: 1\end{array}$ & $\begin{array}{r}0.8 \\
\mathrm{ND}\end{array}$ & $\begin{array}{r}\mathrm{I} \cdot \mathbf{2} \\
\mathrm{ND}\end{array}$ & $\begin{array}{r}0.5 \\
\text { ND }\end{array}$ & $\begin{array}{r}2 \cdot 0 \\
\mathrm{ND}\end{array}$ \\
\hline $\begin{array}{l}\text { Milk triglycerides } \\
\text { I } 8: 0 \\
\text { I } 8: \mathrm{I}\end{array}$ & & & & \\
\hline
\end{tabular}

ND, not detected.

is incorporated into lauric acid, which is then desaturated at the $\beta-\gamma$ position and chainelongated to oleic acid. Mammary tissue of ruminants does not synthesize $\mathrm{C}_{\text {I }} 8$ fatty acids from acetate. The stearic and oleic acids are absorbed direct from the plasma and substantial amounts of oleate in milk fat are derived from the desaturation of stearic acid in mammary tissue. Therefore, as the goat does not normally possess the postulated alternative pathway, evidence for its induction should be obtainable if the desaturase system is inhibited by sterculic acid. Such evidence was not obtained; even after I $7 \mathrm{~d}$ of continuous infusion of sterculic acid, acetate was not incorporated into oleic acid. Thus it is unlikely that the alternative pathway for the synthesis of oleic acid exists, at least in the goat mammary gland.

Unilever gave permission for A. R. Johnson to work as a visiting scientist.

\section{REFERENCES}

Allen, E., Johnson, A. R., Fogerty, A. C., Pearson, J. A. \& Shenstone, F. S. (I967). Lipids 2, 419. Annison, E. F., Linzell, J. L., Fazakerley, S. \& Nichols, B. W. (x967). Biochem. F. 102, 637.

Annison, E. F., Linzell, J. L. \& West, C. E. (1 968). F. Physiol., Lond. 197, 445.

Bickerstaffe, R. \& Annison, E. F. (1968). Biochem. $\mathscr{F}$. Io8, 47 P.

Bickerstaffe, R. \& Annison, E. F. (1970). Comp. Biochem. Physiol. 35, 653.

Bishop, C., Davies, T., Glascock, R. F. \& Welch, V. A. (1969). Biochem. $\mathcal{~ I . ~ I 1 3 , ~ 6 2 9 . ~}$

Coleman, E. C. \& Friedman, L. (1971). F. agric. Fd Chem. 19, 224.

Donaldson, W. E. (1967a). Biochem. biophys. Res. Commun. 26, 539.

Donaldson, W. E. (1967b). Biochem. biophys. Res. Commun. 27, 681.

Freenan, C. P., Noakes, D. E. \& Annison, E. F. (1970). Br. \%. Nutr. 24, 705.

James, A. T., Harris, P. \& Bezard, J. (1968). Eur. F. Biochem. 3, $3^{\text {I } 8 .}$

Johnson, A. R., Murray, K. E., Fogerty, A. C., Kennett, B. H., Pearson, J. A. \& Shenstone, F. S. (I967).

Lipids 2, 3 I6.

Kircher, H. W. (1964). F. Am. Oil Chem. Soc. 4r, 4 .

Lauryssens, M., Verbeke, R., Peeters, G., Garton, G. A., Lough, A. K. \& Duncan, W. R. H. (I960). Archs int. Physiol. Biochim. 68, $5 \mathrm{I}$. 
Linzell, J. L. (1960). F. Physiol., Lond. r53, 492.

Linzell, J. L. (1966). F. Dairy Sci. 59, 307.

Linzell, J. L. (1968). Proc. Nutr. Soc. $27,44$.

Linzell, J. L. (197I). In Lactation p. 26r [I. R. Falconer, editor]. London: Butterworths.

Pearson, J. A., Fogerty, A. C., Johnson, A. R. \& Shenstone, F. S. (I972). Lipids. (In the press.)

Raju, P. K. \& Reiser, R. (1967). F. biol. Chem. 242, 379.

Raju, P. K. \& Reiser, R. (1969). Biochim. biophys. Acta I76, 48. 